\title{
Conjunctival Pedicle Graft in Dogs and Cats: a Retrospective Study of 88 Cases
}

\author{
K. SOONTORNVIPART ${ }^{1,2}$, N. TUNTIVANICH ${ }^{1}$, H. KECOVÁ $^{2}$, P. RAUŠER $^{2}$ \\ ${ }^{1}$ Ophthalmology Clinic, Department of Surgery, Small Animal Teaching Hospital, \\ Faculty of Veterinary Medicine, Chulalongkorn University, Bangkok, Thailand \\ 2 Department of Surgery and Orthopaedics, Small Animal Clinic, \\ University of Veterinary and Pharmaceutical Sciences, Brno, Czech Republic
}

Received July 26, 2002

Accepted November 18, 2002

\section{Abstract}

Soontornvipart K., N. Tuntivanich, H. Kecová, P. Raušer: Conjunctival Pedicle Graft in Dogs and Cats: A Retrospective Study of 88 Cases. Acta Vet. Brno 2003, 72: 63-69.

Seventy-eight dogs and ten cats with corneal lesions, including deep corneal stromal ulcers $(n=32)$, keratomalacia and recurrent erosions $(n=25)$, descemetocoeles $(n=18)$, staphylomas and perforating corneal defects $(n=5)$ and feline corneal sequestrations $(n=8)$ were treated with 3 types of conjunctival pedicle grafts. Breed, age, sex of the patients, size and depth of corneal lesions, suture material used, surgical technique and postoperative application of antibiotics were evaluated to determine their influence on the success rate of conjunctival pedicle graft. The success rate of the therapy was high $(93.18 \%)$ and depended chiefly on the surgical technique employed.

Corneal healing, corneal lesion, corneal ulcer, keratoplasty, dogs, cats

Corneal ulcer is one of the most common corneal diseases seen in small animal practice (Tuntivanich 1993; Boruchoff and Foulks 1990). Animals with corneal ulcers present clinical signs of epiphora, pawing, blepharospasm, photophobia, and corneal opacity (Nasisse 1996; Wilkie and Whittaker 1997). The variety of underlying causes is limitless and includes numerous types of trauma (abrasion, eyelash disease, foreign bodies, exposure due to prolapsed eyes, entropion), chemical exposure (soap, acid, repellents), infection (bacterial, fungal, viral), metabolic diseases (endothelial disease, keratoconjunctivitis sicca, hypoandrogenism) or immune mediated diseases (immune mediated punctate keratitis) (Nečas 1992; Kottman and Nečas 1993; Gelatt and Gelatt 1995; Severin, 1995). Corneal ulcers should be classified according to depth, size, etiology, presence or absence of infection and collagenase activity (Gelatt and Gelatt 1995). Despite early and proper treatment, corneal ulcers may progress rapidly and be advanced at the time of presentation, requiring immediate and aggressive medical and/or surgical intervention (Glaze 1996). If the treatment or the diagnosis is incorrect, the corneal ulcers may continue to enlarge and deepen or develop the punctate keratitis or descemetocoele (Nasis se 1996; Cris pin 1993). Most superficial corneal ulcers will heal rapidly without complication. Thus, only medical therapy using topical antibiotics, mydriatic-cycloplegic agents and artificial tears should be enough to prevent or eliminate infection, alleviate discomfort, and facilitate healing (Slatter 1990; Kern 1990). Surgical therapy should be considered for deep corneal ulcers, recurrent corneal ulcers and stromal melting at initial presentation (Whitley 1991). Descemetocoele and perforated corneal ulcers are considered surgical emergencies. Surgical treatment of choice varies according to size and depth of the corneal defect (Wilkie and Whittaker 1997).

The most important features of treating deep corneal ulcers are to provide mechanical 
support to the weakened cornea and stop further corneal destruction with sound medical therapy (Boruchoff and Foulk 1990). Many surgical techniques are reported, such as corneoscleral grafting (Slatter 1990), conjunctival grafts (Boisjoly et al. 1989), third eyelid flap (Gelatt 1995) and corneal transplantation (Severin 1995). Furthermore, many collagens and contact lenses are used to protect deep corneal ulcers, descemetocoeles and perforating ulcers (Honig and Rapuano 1997). Although third eyelid flap technique is always easily performed in the treatment of superficial corneal ulceration, it has some disadvantages such as corneal wound lacerate from the bulbar side of the third eyelid during eyeball movement (Nasis se 1996). The techniques of corneoscleral grafting and corneal transplantation are performed only occasionally because of their serious complications and postoperative management (Morgan and Abrams 1994).

Conjunctival grafts are performed both in dogs and cats and can originate from either the bulbar or palpebral conjunctiva. These are used to strengthen the weakened corneal stroma, provide fibroblasts, blood vessels, and epithelial cells, which repair defects and offer antimicrobial and antiprotease/anticollagenase activities (Gelatt and Gelatt 1995). Conjunctival grafts have been described in a variety of patterns, the rotational bulbar pedicle graft being the optimal for small animal cornea (Wilkie and Whittaker 1997; Wanichanon et al. 1996). Rotational grafts allow the animal to see around the graft and the veterinarian to evaluate intraocular structures after surgical repair. In addition, assessment of corneal health and pupil dilation is easily performed with a pedicle graft, and topical drug penetration is not inhibited (Tuntivanich et al. 2001).

\section{Materials and Methods}

Study group of animals

The 88 clinical cases of 78 dogs of different breeds (Pekingese (12), Shi - tzu (18), German Shepherd (6), Bulldog (5), Cocker Spaniel (5), Pug (4), Great Dane (2), crossbreed dogs (18), other breeds (8)) and 10 cats (Persian cats (4) and crossbreed cats (6)) with corneal lesions managed with conjunctival pedicle grafts at the Department of Surgery and Orthopaedics of Small Animal Clinic at University of Veterinary and Pharmaceutical Sciences, Brno, Czech Republic and at the Ophthalmology Clinic, Department of surgery at Chulalongkorn University, Bangkok, Thailand in period 2001-2002 were evaluated. The patients were included in this study if the ophthalmological record data was completed with history, signalment, duration of presenting lesion, complete ophthalmic and systemic examination before and after surgery, and complete check-up data. Only healthy patients without any systemic diseases were included in this study.

\section{Evaluation of lesions}

Size, location and depth of corneal lesions were evaluated using slit-lamp biomicroscope (Zeiss H50-10) and fluorescein test (Fluor-I-Strip). Lesions were classified into 5 groups as follows: keratomalacia and recurrent corneal erosions $(n=25)$, deep stromal ulcers $(n=32)$, descemetocoeles $(n=18)$, staphylomas and perforating corneal defects $(n=5)$ and feline sequestrations $(n=8)$. Lesions were further subclassified according to their size. We used the conjunctival pedicle graft technique as a surgical treatment in the cases of serious corneal lesions in dogs. In cats it was mainly performed to cover the cornea after keratectomy in the treatment of feline corneal sequestration ( 8 cases), and only in two cases to treat the corneal ulcer. We evaluated the influence of type and size of the lesion on the success rate of conjunctival pedicle graft (Table 1).

Preoperative preparation

Patients under general anesthesia were placed in lateral or dorsal recumbency with the head positioned to maintain the cornea parallel with the table and the eye looking towards the ceiling. Surgical preparation of the eyes included thorough lavage of conjunctival sacs and cornea with Lugol's or povidone iodine solutions followed by flushing of the eye with sterile saline. The eyelids were scrubbed with povidone iodine solution and washed with sterile saline (B rightbill and B rass 1997). Topical broad-spectrum antibiotics (chloramphenicol, ciprofloxacin, oxytetracycline or neomycin) were administered for 6-24 hours prior to surgery. Intravenous fluids were administered during surgery to ensure adequate renal perfusion.

Conjunctival pedicle graft technique

The recipient site was prepared by keratectomy to debride malacic, necrotic or infected corneal stroma from the ulcer and surrounding cornea (Plate VII, Fig. 1). Keratectomy was performed using Beaver blade No. 64, Martinez corneal dissector, ophthalmic currette, and/or corneal trephine. Donor graft was harvested from the bulbar conjunctiva 
Table 1

Size and depth of corneal lesions and the success rate of conjunctival pedicle graft

\begin{tabular}{|l|c|c|}
\hline Size of corneal lesion (mm) & Number of patients (n) & Success rate (\%) \\
\hline Deep stromal ulcers/ erosions & 28 & $26(92.8 \%)$ \\
$<3 \mathrm{~mm}$ & 19 & $18(94.7 \%)$ \\
$4-5 \mathrm{Mm}$ & 10 & $9(90 \%)$ \\
$5-9 \mathrm{~mm}$ & 15 & $14(93.3 \%)$ \\
\hline Descemetocoele & 3 & $3(100 \%)$ \\
$<5 \mathrm{~mm}$ & & $5(100 \%)$ \\
$5-9 \mathrm{~mm}$ & 5 & $7(87.5 \%)$ \\
\hline Perforating lesion / staphyloma & 8 & \\
$<4$ mm & & \\
\hline Feline corneal sequestration & & \\
\hline
\end{tabular}

(Plate VII, Fig. 2) using colibri forceps and curved blunt-tipped tenotomy scissors. The graft was derived from superior, inferior or lateral bulbar conjunctiva whichever was closer to the lesion to allow the graft traveling the shortest distance. The conjunctiva was elevated 1-2 mm posterior to the limbus and incised. The tips of tenotomy scissors were inserted, curve upward, through the conjunctival incision and the bulbar conjunctiva was bluntly dissected from the underlying Tenon's capsule and episcelral tissues. The graft was then incised from limbus with an incision parallel to and $1 \mathrm{~mm}$ posterior to the limbus. The next incision was at the tip of the graft perpendicular to the first incision and towards the fornix. The final incision was parallel to the first one. The graft was then rotated onto the cornea using two pairs of forceps and placed over the recipient site. The graft was sutured to the cornea with simple interrupted stitches using 8-0 nylon (Nylon, Alcon) in 37 patients and 8-0 polyglactin 910 (Vicryl, Ethicon) in 51 patients (Plate VIII, Fig. 3).

Type of conjunctival pedicle graft

Three types of conjunctival pedicle grafts were performed to cover corneal defects, depending on location of corneal lesions:

Type I: Conjunctival pedicle graft was performed in the vertical direction (the graft was harvested from superior or inferior bulbar conjunctiva, depending on the location of lesion and surgeon's preference) (Severin 1995)

Type II: Conjunctival pedicle graft was performed in the horizontal direction (the graft was harvested from lateral bulbar conjunctiva) (this type of graft was performed in 11 patients in Thailand. Even though it is not recommended in the literature for the dog, surgeons tried to cover the lesions close to lateral limbus using this method.)

Type III: Conjunctival pedicle graft was performed in the oblique direction (Severin 1995)

Fifty-five patients treated with type I conjunctival pedicle graft were divided into two groups: type I - superior and type I - inferior, which referred to the source of graft harvested. Types II and III of conjunctival pedicle graft were performed in 11 and 22 patients, respectively.

Postoperative care

All patients were treated with routine medical therapy for corneal ulcers, including topical atropine 0.5 or $1 \%$ 4-5 times daily, topical antiinflammatory drugs (diclofenac) 4- 5 times daily and topical antibiotics, selected on the basis of microbiology findings or the surgeon's preference (ciprofloxacin (16 cases), gentamicin ( 28 cases), neomycin and polymyxin (4 cases), chloramphenicol (38 cases), oxytetracycline ( 2 cases), $4-5$ times daily. The animals were given Elizabethan collar for at least 14 days to prevent auto mutilation and to reinforce exercise restriction.

Postoperative monitoring

The grafts were monitored for their stability and perfusion once a week for the first four weeks after surgery. Ocular discharge, photophobia and other clinical signs were observed and recorded. Ophthalmological examination was performed at least once a week until the graft was trimmed and the stitches were removed ( $3^{\text {rd }}$, $4^{\text {th }}$ or $6^{\text {th }}$ week after the operation, depending on clinical signs).

Trimming the graft and removal of the stitches

Conjunctival pedicle grafts were trimmed using colibri forceps and tenotomy scissors in topical anesthesia with $0.5 \%$ proparacaine or $0.4 \%$ oxybuprocaine (some fractious animals required sedation or general anesthesia). The portion of the graft that was not attached to the cornea was elevated and resected. Topical $2.5 \%$ phenylephrine or 
epinephrine diluted to 1:10 000 was used to induce conjunctival vasoconstriction and thus minimize haemorrhage (Nichols 1997). In the case of patients with non-absorbable sutures and also in approximately $80 \%$ of patients with absorbable sutures, the stitches were removed in the time of removing the graft.

After trimming the graft, antibiotics and topical corticosteroids were administered to modify scar formation for the period of 1-3 months, depending on the surgeon's demand.

Data collection and statistic analysis

Clinical signs, sizes of corneal scars and complications were used to evaluate the outcome of the conjunctival pedicle graft technique after surgery. All ocular clinical signs related to corneal ulcer, ophthalmic clinical data and success of any techniques were also collected and analyzed using $\chi^{2}$-test and ANOVA test.

The success rate of this technique was evaluated. The criteria included success of graft attachment, amount of corneal scar tissue formation after corneal remodeling (final scar must be less than $10 \%$ of the size of original lesion) and completeness of corneal healing without any serious complications.

\section{Results}

Table 2 shows breeds of dogs affected with deep corneal ulcers. Brachiocephalic dogs such as Pekingese, Shi-tzu, Bulldog or Pug tend to be affected more frequently (39 out of 78 cases; $50 \%$ ), whereas other breeds only occasionally. In our collection of patients the cause of ulcer was mostly presumed to be traumatic. On clinical examination patients exhibited pain, blepharospasm, protrusion of the nictitating membrane and/or epiphora. The stages of corneal healing and vascularization were variable.

Table 2

Breed, number of patients and the success rate of conjunctival pedicle graft in the treatment of corneal ulcer

\begin{tabular}{|l|l|c|c|}
\hline Species & Breed & Number of patients & Success rate (\%) \\
\hline \multirow{5}{*}{ Dog } & Pekingese & 12 & $12(100 \%)$ \\
\cline { 2 - 4 } & Shi - tzu & 18 & $17(94.4 \%)$ \\
\cline { 2 - 4 } & Bulldog & 5 & $4(80 \%)$ \\
\cline { 2 - 4 } & Pug & 4 & $3(75 \%)$ \\
\cline { 2 - 4 } & Cocker spaniel & 5 & $5(100 \%)$ \\
\cline { 2 - 4 } & Great Dane & 2 & $2(100 \%)$ \\
\cline { 2 - 4 } & German Shepherd & 6 & $6(100 \%)$ \\
\cline { 2 - 4 } & Crossbreed & 18 & $17(94.4 \%)$ \\
\cline { 2 - 4 } & Other breed & 8 & $7(87.5 \%)$ \\
\hline \multirow{5}{*}{ Cat } & Persian & 4 & $4(100 \%)$ \\
\cline { 2 - 4 } & Crossbreed & 6 & $5(83.3 \%)$ \\
\hline
\end{tabular}

The success rate of conjunctival pedicle graft technique for the treatment of deep corneal ulcers was very high (93.18\%). It did not significantly depend on breed, age and sex of the patient, size and depth of corneal lesion, nor on selection of suture material and antibiotics. The success rate depended significantly on surgical techniques and type of technique performed $(\mathrm{p}<0.05)$. Pedicle graft of the types I and III had significantly higher success rate than the type II $(\mathrm{p}<0.05)$ (Table 3$)$.

Graft failure was detected in 6 patients (6.81\%). Reasons of graft failure as expressed by surgeons and ophthalmologists were:

- too thick pedicle graft and/or insufficient preparation of the recipient site $(n=2)$

- pedicle graft was placed in horizontal line $(n=3)$

- self trauma $(n=1)$

Once a month after trimming the graft, all patients were examined for scar remodeling. The third month 48 patients had tiny corneal opacities undetectable by eye, 24 patients had 
Table 3

Type of conjunctival pedicle graft and the success rate

\begin{tabular}{|l|c|c|}
\hline Type of conjunctival pedicle graft & Number of patients & Success rate outcome (\%) \\
\hline Type I - superior & 31 & $30(96.7 \%)$ \\
\hline Type I - inferior & 24 & $24(100 \%)$ \\
\hline Type II & 11 & $7(63.6 \%)$ \\
\hline Type III & 22 & $21(95.4 \%)$ \\
\hline
\end{tabular}

small scars (less than $20 \%$ of original lesion), which did not affect normal vision. In 8 patients corneal degeneration developed, but did not impair normal vision. Two patients had developed some degree of leukoma. In the remaining 6 patients the pedicle graft failed and cornea was further protected with third eyelid flap together with medical therapy. All of these patients developed large scar formations and need long-term treatment and frequent check-ups. We found that the patients with permanent scar and leukoma had developed staphyloma and/or severe anterior uveitis prior to the surgery.

\section{Discussion}

Corneal ulceration is common in both dogs and cats and can be primary or secondary to other ophthalmic or systemic diseases. Ulcerative keratitis and deep stromal ulcers are frequently seen in brachiocephalic breeds and usually present as a central and/or paracentral ulcers with rapid onset. Pathogenesis of ulcers in these breeds involves several contributory factors. These breeds exhibit subnormal corneal sensitivity, blink less frequently, have central thinning of the precorneal tear film and exhibit relative lagophthalmos (Kern 1990). Furthermore, predisposing factors such as distichiasis, trichiasis, and nasal fold trichiasis are also reported. Recurrent corneal erosions, descemetocoeles, staphylomas and feline sequestrations are also commonly found conditions in small animal clinical practice (McNeil 1997).

Conjunctival pedicle graft is a surgical treatment with successful rate exceeding $90 \%$ (Wilkie and Whittaker 1997). This technique promotes corneal healing by strengthening weakened corneal stroma, providing fibroblasts, blood vessels and epithelial cells and offering antimicrobial, antiprotease and anticollagenase properties (Morgan and Abrams 1994). Furthermore the aim of the graft is to cover the defect and its closest surroundings, achieving conjunctival to corneal epithelium cell apposition over as much of the graft circumference as possible. Pedicle graft allows edge to edge apposition over at least $270^{\circ}$ of the graft margin and will ensure rapid acceptance of the graft, epithelial cell contact inhibition and cell to cell adherence and minimize scar formation (Wilkie and Whittaker 1997).

Postoperative trimming of graft is required to sever the blood supply to the graft, allowing the corneal attachment to atrophy and undergo fibrosis, thus minimizing scar formation. At the time of graft trimming, both absorbable and non-absorbable suture materials should be removed to decrease vascular reaction and subsequent scar formation (Gelatt and Gelatt 1995). Scar remodeling occurs over several months and final results vary from an insignificant opacity to a dense leukoma.

Failure of conjunctival pedicle graft has numerous causes such as poor surgical technique, including inadequate debridement of the recipient site, improper suture placement, excessive graft tension or thickness, excessive size of the graft, which overlaps the ulcer edge failing to achieve epithelial-to-epithelial apposition. Above all, failure of conjunctival pedicle graft may be caused by the use of a conjunctival graft in a situation in which corneal graft would have been more appropriate and failure to control infection (Wilkie and Whittaker 1997; Tuntivanich et al. 2001). 
This study shows that the type II of the conjunctival pedicle graft had lower success rate than types I and III. This graft failure may be caused by the direction of eyelid blinking, especially if the graft is so thick that the eyelid movement can interfere with the adherence of graft.

According to this study, neither breed, age, sex of patients, nor size and depth of corneal lesions have any influence on success rate of this technique. The only important factors are the surgical technique used and the type of conjunctival pedicle graft.

Although only a few reports about this technique are published, it is commonly recommended for treatment of corneal lesions such as deep stromal ulcers, descemetoceles, perforated corneas, recurrent corneal erosions and feline sequestrations (Pentlage 1996) in many ophthalmologic publications (B logg et al. 1989; Kirschner 1990; Morgan 1994; Boruchoff and Foulks 1990; Honig and Rapuano 1997; Gelatt and Gelatt 1995).

\section{Použití stopkatého štěpu spojivky u psů a koček: retrospektivní studie 88 klinických případů}

Léčili jsme 78 psů a 10 koček s rohovkovými lézemi zahrnujícími keratomalácii a rekurentní rohovkové eroze $(n=25)$, hluboké rohovkové vředy $(n=32)$, descemetocoele $(\mathrm{n}=18)$, stafylomy a perforující defekty rohovky $(\mathrm{n}=5)$ a felinní korneální sekvestry $(n=8)$ s použitím 3 typů stopkatých štěpů spojivky. Bylo zhodnoceno možné ovlivnění úspěšnosti léčby korneálních defektů stopkatým štěpem spojivky v závislosti na plemeni, věku a pohlaví pacienta, velikosti a hloubce lézí rohovky, typu použitého šicího materiálu, použité chirurgické technice a pooperačně podávaných antibioticích. Úspěšnost této metody léčby rohovkových lézí byla vysoká $(93,18 \%)$, významné odchylky byly zaznamenány pouze v závislosti na použité chirurgické technice.

\section{Acknowledgements}

The authors greatly thank to Prof. P. Tuntivanich, all staff in Ophthalmology Clinic, Department of Surgery, Small animal teaching Hospital, Faculty of Veterinary Medicine, Chulalongkorn University, Bangkok, Thailand, MVDr. Michal Vlašín, PhD. and all staff in Department of Surgery and Orthopaedics, Small Animal Clinic, University of Veterinary and Pharmaceutical Sciences, Brno, Czech Republic for their assistance.

\section{References}

BLOGG JR, STANLEY RG, DUTTON AG 1989. Use of conjunctival pedicle graft in the management of feline keratitis nigrum. J Small Anim Pract 30: 678-679

BOISJOLY HM, STANLEY RG, DUTTON AG 1989. Use of conjunctival graft in the management of feline keratitis nigrum. J Small Anim Pract 30: 678-680

BORUCHOFF SA, FOULKS GN 1990. Corneal surgery. In: SPAETH GL: Ophthalmic Surgery: Principle and Practice, W.B. Saunders. Philadelphia, $2^{\text {nd }}$ ed., pp. 176-180

BRIGHTBILL FS, BRASS RE 1997. Preoperative evaluation of the keratoplasty patient. In: KACHMER JH, MANNIS MJ,HOLLAND EJ: Cornea: Surgery of the Cornea and Conjunctiva, Vol III. Mosby-Year Book, St. Louis, pp. 1563-1581

CRISPIN SM 1993. The preocular tear film and condition of the conjunctiva and cornea. In: CRISPIN SM: Manual of small animals ophthalmology. B.S.A.V.A., London, pp. 137-172

GELATT KN, GELATT JP 1995: Corneal and Intraocular Procedures In: GELATT KN, GELATT JP: Handbook of Small Animal Ophthalmic Surgery - Vol. 2, Pergamon, New York, pp. 127-178

GELATT KN 1996: Corneal Diseases in the Dog. In: GLAZE MB: The compendium collection: Ophthalmology in Small animal practice. pp. 107-113

GELATT KN 1996: Feline ophthalmology. In:GLAZE MB: The compendium collection:Ophthalmology in Small animal practice. pp. 201-209

HONIG MA, RAPUANO CJ 1997: Management of corneal perforations. In: KACHMER JH, MANNIS MJ, HOLLAND EJ: Cornea: Surgery of the Cornea and Conjunctiva - Vol III. Mosby-Year Book, St.Louis, pp. 18151845

KERN TJ 1990: Ulcerative Keratitis. Vet Clin North Am Small Anim Pract 20: 643-670

KIRSCHNER SE 1990: Persistent corneal ulcers: What to do when ulcers won't heal. Vet Clin North Am Small Anim Pract 20: 627-654 
KOTTMAN J, NEČAS A 1993: Nemoci rohovky. Sborník referátů z XXVIII. zasedání odborné sekce chirurgie, ortopedie a rentgenologie Společnosti veterinárních lékařů, Košice, 3.-4. prosince 1993, pp. 10-14

MCNEIL JI 1997: Indications and outcomes. In: KACHMER JH, MANNIS MJ, HOLLAND EJ: Cornea: Surgery of the Cornea and Conjunctiva - Vol III. Mosby-Year Book, St. Louis, pp. 1551-1558

MORGAN RV 1994: Feline corneal sequestration. A retrospective study of 42 cases (1989-1991). J Am Anim Hosp Assoc 30: 24-27

MORGAN RV, ABRAMS KL 1994: A Comparison of six different therapies for persistent corneal erosions in dogs and cats. Vet Comp Ophthal 4: 38

NASISSE MP 1996: Canine Ulcerative Keratitis. In: GLAZE MB: The compendium collection: Ophthalmology in Small animal practice. pp. 45-59

NEČAS A 1992: Onemocnění řas u psů. Sborník I. kongresu České a Slovenské asociace veterinárních lékařů malých zvířat, Košice, 22.-24. října 1992, pp. 22-25

NICHOLS BD 1997: Conjunctival flaps. In: KACHMER JH, MANNIS MJ, HOLLAND EJ: Cornea: Surgery of the Cornea and Conjunctiva - Vol III. Mosby-Year Book, St. Louis, pp. 1903-1918

PENTLAGE VW 1996: Corneal Sequestration in Cats. In: GLAZE MB: The compendium collection: Ophthalmology in Small animal practice. pp. 45-59

SEVERIN GA 1995: Cornea. In: SEVERIN GA: Severin's veterinary ophthalmology notes. CSU Press, Fort Collins, $3^{\text {rd }}$ ed. pp. $121-152$

SLATTER D 1990: Cornea and sclera. In: SLATTER D: Fundamentals of Veterinary Ophthalmology. W.B. Sauders, Philadelphia, pp. 545-628

STARTUP FG 1988: Corneal necrosis and sequestration in the cat: A review and record of 100 cases. J Small Anim Pract 29: 476-479

TUNTIVANICH P 1993: Cornea. In: TUNTIVANICH P. (ed): Eye diseases in animal. Chulalongkorn University, Bangkok, pp. 107-127

TUNTIVANICH P, TUNTIVANICH N, SOONTORNVIPART K 2001: Cornea. In: TUNTIVANICH P(ed): Veterinary Ophthalmology. Chulalongkorn University, Bangkok, $2^{\text {nd }}$ ed, pp. 95-120

WANICHANON C, BOONVITTAYA J, TUNTIVANICH N, TUNTIVANICH P, BRAHMASA A, SOONTORNVIPART K 1996: Conjunctival Pedicle graft in Dogs. Thai J Vet Med 26: 33-49

WHITLEY RD 1991: Canine cornea. In: GELATT KN: Veterinary Ophthalmology. Lea \& Febiger, Philadelphia, $2^{\text {nd }}$ ed. pp. 307-321

WILKIE DA, WHITTAKER C 1997: Surgery of the Cornea. Vet Clin North Am Small Anim Pract 27: 1067-1107 
Plate VII

Soontornvipart K. et al.: Special Properties... pp. 63-69

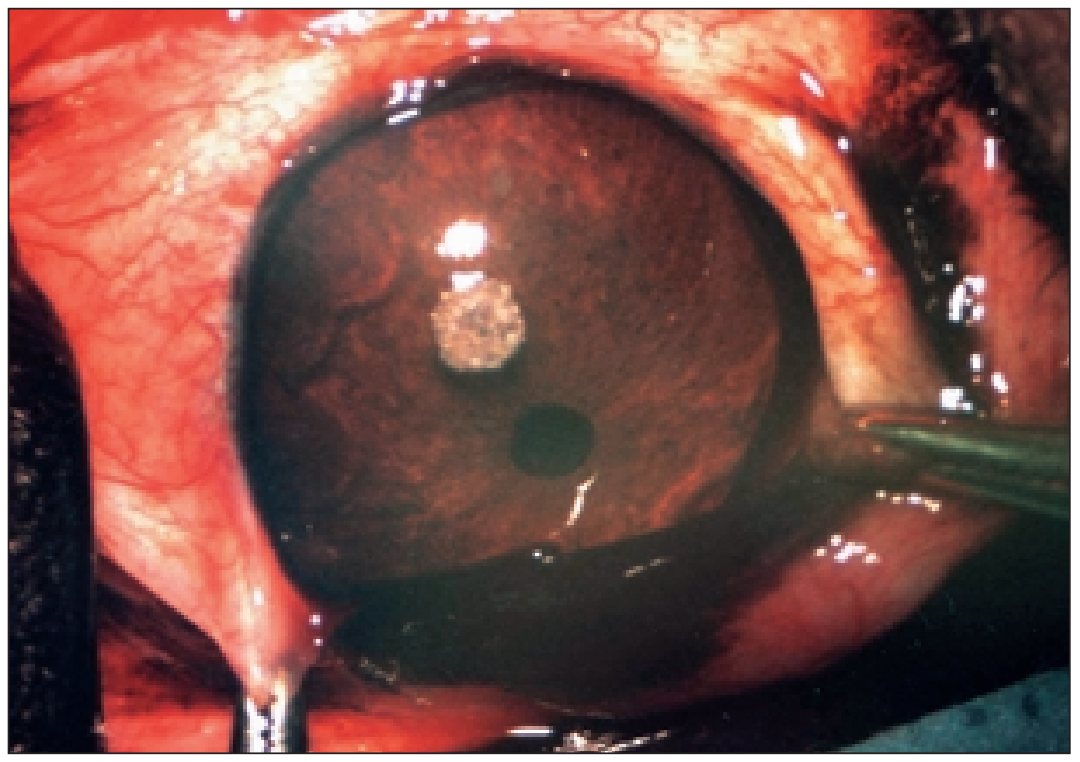

Fig. 1: Corneal lesion after preparing the recipient site.

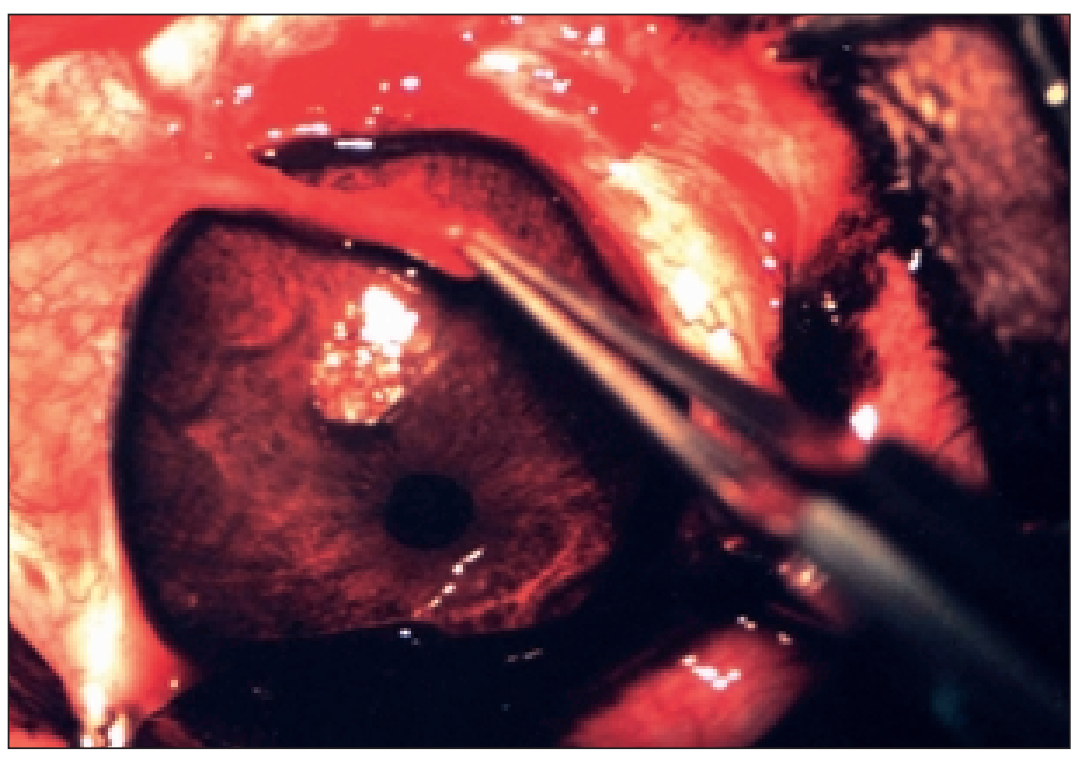

Fig. 2: Harvesting of the conjunctival pedicle graft. 
Plate VIII

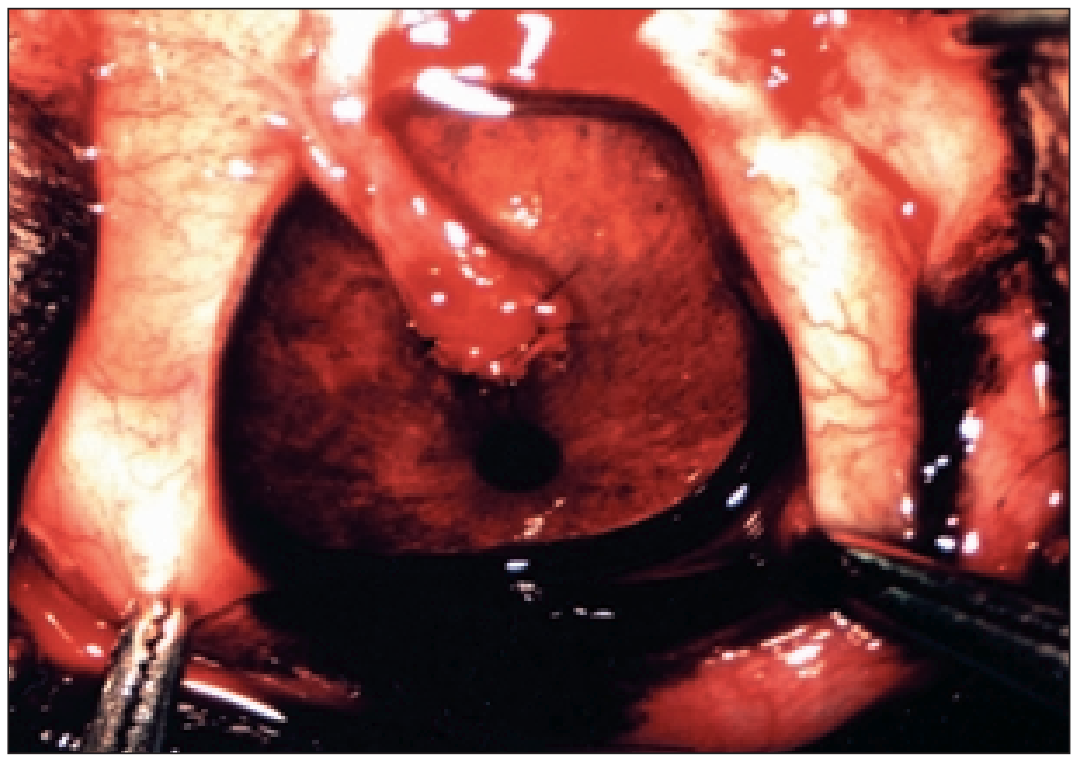

Fig. 3: Conjunctival pedicle graft sutured to the cornea. The graft covers corneal lesion. 